\title{
ANALISIS ADVERSE DRUG REACTIONS OBAT ANTI RETROVIRAL PADA PENGOBATAN PASIEN HIV/AIDS DI RSUD GUNUNG JATI CIREBON TAHUN 2013
}

\section{THE ANALYSIS OF ADVERSE DRUG REACTIONS OF ANTIRETROVIRAL THERAPY AMONG THE PATIENTS WITH HIV/ AIDS IN RSUD GUNUNG JATI CIREBON WITHIN THE YEAR 2013}

\author{
Nur Rahmi Hidayati ${ }^{1}$, Syamsudin Abdillah ${ }^{2}$, Sesilia A. Keban ${ }^{2}$ \\ ${ }^{1}$ Akademi Farmasi Muhammadiyah Cirebon \\ Jl. Cideng Indah no. 3 Cirebon \\ ${ }^{2}$ Fakultas Farmasi Universitas Pancasila \\ Srengseng Sawah, Jagakarsa, Jakarta \\ Email:Salsabilla_83@yahoo.com
}

Submitted: 31-12-2015

Reviewed: 29-02-2016

Accepted: 26-04-2016

\begin{abstract}
ABSTRAK
Acquired Immuno Deficiency Syndrome (AIDS) merupakan suatu penyakit yang disebabkan oleh infeksi virus Human Immuno Deficiency Virus (HIV). Untuk terapinya digunakan terapi antiretroviral. Masalah yang muncul dari penggunaan obat antiretroviral (ARV) adalah munculnya reaksi obat yang tidak dikehendaki (adverse drug reaction). Tujuan penelitian ini adalah untuk mengidentifikasi dan menganalisis kejadian adverse drug reaction dari penggunaan obat antiretroviral pada pengobatan pasien HIV/AIDS yang terjadi di RSUD Gunung Jati Cirebon. Pengujian ini melibatkan 122 pasien. Data diperoleh dari rekam medik dan formulir wawancara pasien. Hasil yang diperoleh dilakukan analisis deskriptif untuk data demografi pasien, jenis regimen ARV, lama terapi $\mathrm{ARV}$, dan jenis adverse drug reaction (ADR) yang terjadi. Hasil penelitian menunjukkan terjadi adverse drug reaction (ADR) pada penggunaan obat antiretroviral pada pengobatan pasien HIV/AIDS di RSUD Gunung Jati Cirebon. Regimen ARV yang paling banyak digunakan adalah kombinasi Zidovudin + Lamivudin + Nevirapine/Efavirenz (AZT+3TC+EFV) sebanyak 31,2\% (38 orang). Lama terapi ARV di Klinik Seroja RSUD Gunung Jati Cirebon paling banyak adalah $>2$ tahun -4 tahun sebesar $28,7 \%$ (35 orang). Jenis adverse drug reaction (ADR) yang terjadi pada penggunaan obat antiretroviral pada pengobatan pasien HIV/AIDS di RSUD Gunung Jati Cirebon adalah: sakit kepala $(22,1 \%)$, kelelahan $(6,8 \%)$, anemia $(9,3 \%)$, gatal $(14,4 \%)$, mual/muntah $(20,1 \%)$, diare $(7,2 \%)$, lipodistrofi $(2,0 \%)$, ruam kulit $(11,3 \%)$, perubahan warna kulit $(1,6 \%)$, neuropati $(1,6 \%)$ dan gangguan tidur $(3,6 \%)$.
\end{abstract}

Kata kunci: HIV/AIDS, Anti Retroviral (ARV), Adverse Drug Reaction (ADR).

\begin{abstract}
Acquired Immunodeficiency Syndrome (AIDS) is a disease caused by infection with Human Immunodeficiency Virus (HIV). The pharmacology treatment for the infection was antiretroviral therapy. The problem from the use of antiretroviral drugs (ARV) is the emergence of unwanted drug reactions (adverse drug reaction). The purpose of this study was to identify and analyze the incidence of adverse drug reactions from the use of antiretroviral drugs in the treatment of patients with HIV / AIDS that occurred in RSUD Gunung Jati Cirebon. This study involves 122 patients. Data were obtained from medical records and patient interview form. The data were evaluated with a descriptive
\end{abstract}


analysis of demographic profile of patients and the percentage of adverse drug reaction (ADR) The results showed an adverse drug reaction (ADR) on the use of antiretroviral drugs in the treatment of patients with HIV / AIDS in RSUD Gunung Jati Cirebon. ARV regimens are the most widely used is the combination of Zidovudine + Lamivudine + Nevirapine / Efavirenz (AZT + 3TC + EFV) as much as $31.2 \%$ (38 people). Duration of therapy ARV in Seroja Clinic RSUD Gunung Jati Cirebon most is> 2 years - 4 years $28.7 \%$ (35 people). Types of adverse drug reaction (ADR), which occurs in the use of antiretroviral drugs in the treatment of patients with HIV / AIDS in RSUD Gunung Jati Cirebon include: headache $(22.1 \%)$, fatigue $(6.8 \%)$, anemia $(9.3 \%)$, itching $(14.4 \%)$, nausea / vomiting $(20.1 \%)$, diarrhea $(7.2 \%)$, lipodystrophy $(2.0 \%)$, rash (11.3\%), skin discoloration (1.6\%), neuropathy $(1.6 \%)$ and sleep disorders (3.6\%).

Keywords: HIV/AIDS, Anti Retroviral (ARV), Adverse Drug Reaction (ADR).

\section{PENDAHULUAN}

Acquired Immuno Deficiency Syndrome (AIDS) merupakan suatu penyakit yang disebabkan oleh infeksi virus Human Immunodeficiency Virus (HIV). Virus ini menyebabkan kerusakan atau penurunan pada sistem kekebalan tubuh manusia (Thorp, 2008). Virus ini ditemukan dalam 2 bentuk utama yaitu HIV-1, yang paling umum di seluruh dunia, dan HIV-2, yang paling umum di Afrika Barat (Dyke et al, 2006).

Jumlah penderita HIV/AIDS di dunia mengalami peningkatan. Hal ini dapat dilihat dari data UNAIDS report pada akhir tahun 2012, yang menunjukkan terdapat 35,3 juta penderita HIV, dengan perkiraan 32,1 juta orang dewasa dengan usia 15 - 49 tahun di seluruh dunia hidup dengan HIV.Data dari Departemen Kesehatan (Depkes) triwulan Juli - September 2013, di Indonesia diperkirakan terdapat 118.792 orang dengan HIV positif. Di Kota Cirebon, Prevalensi (jumlah kasus dibagi jumlah penduduk dikali 100 persen), penderita HIV AIDS menempati ranking pertama se-Jawa Barat (Anonim, 2013).

Kombinasi antiretroviral merupakan dasar pelaksanaan pemberian terapi antiretroviral terhadap pasien HIV/AIDS, karena dapat mengurangi resistensi, menekan replikasi HIV secara efektif sehingga penularan, infeksi oportunistik, dan komplikasi lainnya dapat dihindari serta meningkatkan kualitas dan harapan hidup dari pasien HIV/AIDS. Terapi secara dini dapat melindungi sistem kekebalan tubuh dari kerusakan oleh virus HIV (Montessori et al, 2004).

Masalah yang muncul dari penggunaan obat antiretroviral (ARV) salah satunya adalah munculnya reaksi obat yang tidak dikehendaki (adverse drug reaction). Adverse drug reaction (ADR) adalah reaksi obat yang merugikan, timbul efek yang tidak diinginkan pada dosis terapi. Beberapa adverse drug reaction yang sering muncul setelah penggunaan obat antiretroviral (ARV) adalah mual, ruam, nyeri perut, hiperlaktasemia dan asidosis laktat, lipodistrofi, hiperlipidemia, anemia atau neutropenia (Anonim, 2004). Penelitian McLigeyo dkk, Silva dan Alchieri, menemukan terjadinya efek lipodistrofi karena penggunaan obat anti retroviral pada pengobatan HIV/AIDS di Kenya dan Brazil (McLigeyo et al, 2012; Silva, 2013). Penelitian dari Qamariyah dkk (2012) menyebutkan bahwa ADR yang sering terjadi pada penderita AIDS adalah keluhan nafsu makan yang menurun (90\%), sakit kepala (80\%), sulit tidur $(80 \%)$ dan mual $(70 \%)$.

Penelitian Ramadian dan Riztriawan (2010) yang dilakukan di salah satu rumah sakit umum di Jakarta menemukan terjadinya adverse drug reaction dari penggunaan antiretroviral berupa anemia, mual, fatigue, rash (kulit kemerahan), neuropati, peningkatan enzim AST/ALT, hiperlaktat. Studi yang dilakukan di Nigeria pada April 2009 - Desember 2010 menemukan ADR dari penggunaan terapi ARV yang paling banyak terjadi adalah ruam kulit, neuropati perifer dan sakit kepala (Kenneth et al, 2013). Studi yang dilakukan di Brazil pada tahun 2001 - 2003 menemukan ADR yang banyak terjadi adalah mual dan muntah (Menezes et al, 2006). Studi yang dilakukan di Douala pada Januari 2003 Desember 2009 menemukan terjadinya ADR neuropati perifer, sakit kepala, insomnia, gangguan gastrointestinal, lipodistrofi dan anemia karena penggunaan terapi antiretroviral (Henry \& Simon, 2012).

Farmasis memiliki peranan penting dalam keberhasilan suatu terapi. Salah satu tanggung jawab profesi seorang farmasis adalah memberikan layanan kefarmasian yang berorientasi pada 
pasien, yang disebut dengan pharmaceutical care (asuhan kefarmasian). Dalam terapi obat pasien, seorang farmasis diharapkan dapat mengidentifikasi masalah-masalah yang berkaitan dengan penggunaan obat (Drug Related Problems) baik yang telah terjadi atau yang berpotensi untuk terjadi. Dengan penurunan kejadian adverse drug reaction (ADR) maka dapat meningkatkan kepatuhan penggunaan obat pada pasien (Anonim, 2004).

RSUD Gunung Jati Cirebon merupakan rumah sakit tipe B Pendidikan. Sebagai salah satu rumah sakit rujukan se-Wilayah III Cirebon bagi orang dengan HIV dan AIDS (ODHA), rumah sakit ini memiliki fasilitas pelayanan obat anti retroviral. Pasien dengan HIV/AIDS memiliki ruang perawatan khusus yang bernama Klinik Seroja. Pelayanan kesehatan terhadap pasien dengan obat anti retroviral di RSUD Gunung Jati Cirebon dilaksanakan atas dasar Surat Keputusan Direktur RSUD Gunung Jati Cirebon, Nomor: 443.05/Kep.104-RSUD.GJ/2007, tanggal 8 Oktober 2007, tentang Pembentukan Kembali Tim Penanggulangan AIDS di RSUD Gunung Jati Cirebon. Berdasarkan laporan perkembangan HIV/AIDS triwulan II tahun 2012, jumlah pasien HIV/AIDS di RSUD Gunung Jati Cirebon adalah sebanyak 116 pasien dewasa dan 6 pasien anak ( Anonim, 2012). Penelitian ini bertujuan melakukan analisis untuk mengetahui data demografi pasien, jenis regimen ARV, lama terapi ARV, dan jenis adverse drug reaction (ADR) yang terjadi pada pengobatan pasien HIV/AIDS di RSUD Gunung Jati Cirebon.

\section{METODE PENELITIAN}

\section{Bahan}

Penelitian ini merupakan penelitian observasional dengan pengambilan data secara prospektif. Penelitian dilakukan di Klinik Seroja RSUD Gunung Jati Cirebon. Subjek penelitian adalah pasien HIV/AIDS dewasa yang mendapatkan terapi ARV pada tahun 2013, yang datang berobat secara rutin ke Klinik Seroja RSUD Gunung Jati Cirebon dan bersedia mengikuti penelitian. Jumlah sampel berjumlah 122 pasien.

Data primer dalam penelitian ini berupa daftar pertanyaan peneliti yang digunakan untuk menunjang data rekam medik. Sedangkan data sekunder dalam penelitian ini meliputi data rekam medik pasien yang berisi data demografi pasien meliputi usia, jenis kelamin, pendidikan, pekerjaan, faktor resiko dan status pernikahan, jenis regimen ARV, lama terapi ARV, serta jenis adverse drug reaction yang terjadi pada pengobatan pasien HIV/AIDS di RSUD Gunung Jati Cirebon.

\section{Metode}

Data yang dianalisis secara deskriptif meliputi data demografi pasien meliputi usia, jenis kelamin, pendidikan, faktor resiko, status pernikahan, jenis regimen ARV, lama terapi ARV, serta jenis adverse drug reaction yang terjadi pada pengobatan pasien HIV/AIDS di RSUD Gunung Jati Cirebon.

\section{Jalannya Penelitian}

Pasien diberikan penjelasan lisan dan tertulis mengenai penelitian dan jika bersedia diminta menandatangani formulir informed consent. Data diambil secara langsung melalui daftar pertanyaan peneliti terhadap subyek terpilih dengan menggunakan rekam medik untuk mengetahui demografi pasien, jenis regimen ARV, lama terapi ARV dan jenis adverse drug reaction yang terjadi. Hasil-hasil yang didapat kemudian dicatat dan selanjutnya dilakukan analisis.

\section{Analisis Data}

Analisis data berupa uji frekuensi (deskriptif) data demografi pasien meliputi usia, jenis kelamin, pekerjaan, riwayat penyakit, riwayat penggunaan obat pasien, jumlah pasien serta jenis adverse drug reaction yang terjadi pada pengobatan pasien HIV/AIDS di RSUD Gunung Jati Cirebon. 


\section{HASIL DAN PEMBAHASAN}

\section{Demografi Pasien}

Demografi Pasien HIV/AIDS di Klinik Seroja RSUD Gunung Jati Cirebon Tahun 2013 dapat dilihat pada Tabel I

Tabel I. Demografi Pasien HIV/AIDS di RSUD Gunung Jati Cirebon Tahun 2013

\begin{tabular}{|c|c|c|}
\hline \multirow{2}{*}{$\begin{array}{l}\text { Demografi Pasien } \\
\text { Jenis Kelamin }\end{array}$} & \multicolumn{2}{|c|}{$\mathrm{n}=122$} \\
\hline & Jumlah & Presentase \\
\hline Pria & 59 & 48,4 \\
\hline Wanita & 63 & 51,6 \\
\hline \multicolumn{3}{|l|}{ Usia } \\
\hline $20-29$ & 45 & 36,9 \\
\hline $30-40$ & 77 & 63,1 \\
\hline \multicolumn{3}{|l|}{ Pendidikan } \\
\hline SD & 12 & 9,8 \\
\hline SMP & 19 & 15,6 \\
\hline SMA & 74 & 60,7 \\
\hline UNIVERSITAS & 17 & 13,9 \\
\hline \multicolumn{3}{|l|}{ Pekerjaan } \\
\hline Swasta & 31 & 25,4 \\
\hline PNS & 1 & 0,8 \\
\hline Tidak Kerja & 27 & 22,1 \\
\hline IRT & 14 & 11,5 \\
\hline Lain-lain & 49 & 40,2 \\
\hline \multicolumn{3}{|l|}{ Faktor Resiko } \\
\hline IDU & 27 & 22,1 \\
\hline Homoseksual & 7 & 5,7 \\
\hline Heteroseksual & 84 & 68,9 \\
\hline Perinatal & 0 & 0 \\
\hline Suami IDU & 4 & 3,3 \\
\hline \multicolumn{3}{|l|}{ Status Pernikahan } \\
\hline Menikah & 85 & 69,7 \\
\hline Belum Menikah & 17 & 13,9 \\
\hline Bercerai & 20 & 16,4 \\
\hline
\end{tabular}

Hasil demografi pasien seperti yang tertera pada Tabel I, jenis kelamin pasien HIV/AIDS yang menggunakan terapi ARV di Klinik Seroja RSUD Gunung Jati Cirebon terdiri dari 48,4\% pasien pria dan $51,6 \%$ pasien wanita. Kisaran usia pasien yang masuk dalam penelitian ini berusia 20-40 tahun. Berdasarkan tingkat pendidikan terlihat kelompok yang paling besar adalah dengan tingkat pendidikan menengah atas (SMA) yaitu sebesar 60,7\%. Berdasarkan jenis pekerjaan kelompok yang paling besar adalah dengan jenis pekerjaan lain-lain (selain swasta, PNS, tidak kerja dan IRT) yaitu sebesar 40,2\%. Berdasarkan faktor terjadinya HIV/AIDS terlihat kelompok yang paling besar adalah heteroseksual dengan presentasi sebesar $68,9 \%$, dan diikuti dengan IDU (injecting drug user) yaitu sebesar $22,1 \%$. Hal ini juga sesuai dengan data statistik kasus HIV/AIDS di Indonesia dilaporkan sampai dengan September 2013 dimana faktor resiko yang paling banyak adalah heteroseksual yaitu sebesar $26,2 \%$ dan diikuti oleh IDU sebesar 7,8 \%. Selanjutnya berdasarkan status pernikahan terlihat kelompok yang paling besar adalah dengan status pernikahan menikah, yaitu 69,7\%.

\section{Jenis Regimen ARV}

Penggunaan Anti Retroviral (ARV) pada pasien HIV/AIDS di Klinik Seroja RSUD Gunung Jati Cirebon terdapat beberapa regimen obat. Regimen obat ARV yang digunakan yaitu:

a. Zidovudin-Lamivudin-Nevirapine / AZT $+3 T C+N V P$ (Duviral-Neviral)

b. Zidovudin-Lamivudin-Efavirenz / AZT+3TC+EFV (Duviral-Efavirenz) 
c. Stavudin-Lamivudin-Nevirapine / d4T $+3 \mathrm{TC}+\mathrm{NVP}$ (Staviral-Hiviral-Neviral)

d. Stavudin-Lamivudin-Efavirenz / d4T+3TC+EFV (Staviral-Hiviral-Efevirenz)

e. Tenofovir-Lamivudin-Efavirenz / TDF+3TC+EFV (Tenofovir-Hiviral-Efavirenz)

f. Tenofovir-Lamivudin-Nevirapine / TDF+3TC+NVP (Tenofovir-Hiviral-Neviral)

g. Tenofovir-Lamivudin-Lopinavir/Ritonavir / TDF+3TC+LPV/r (Tenofovir-Hiviral-Aluvia)

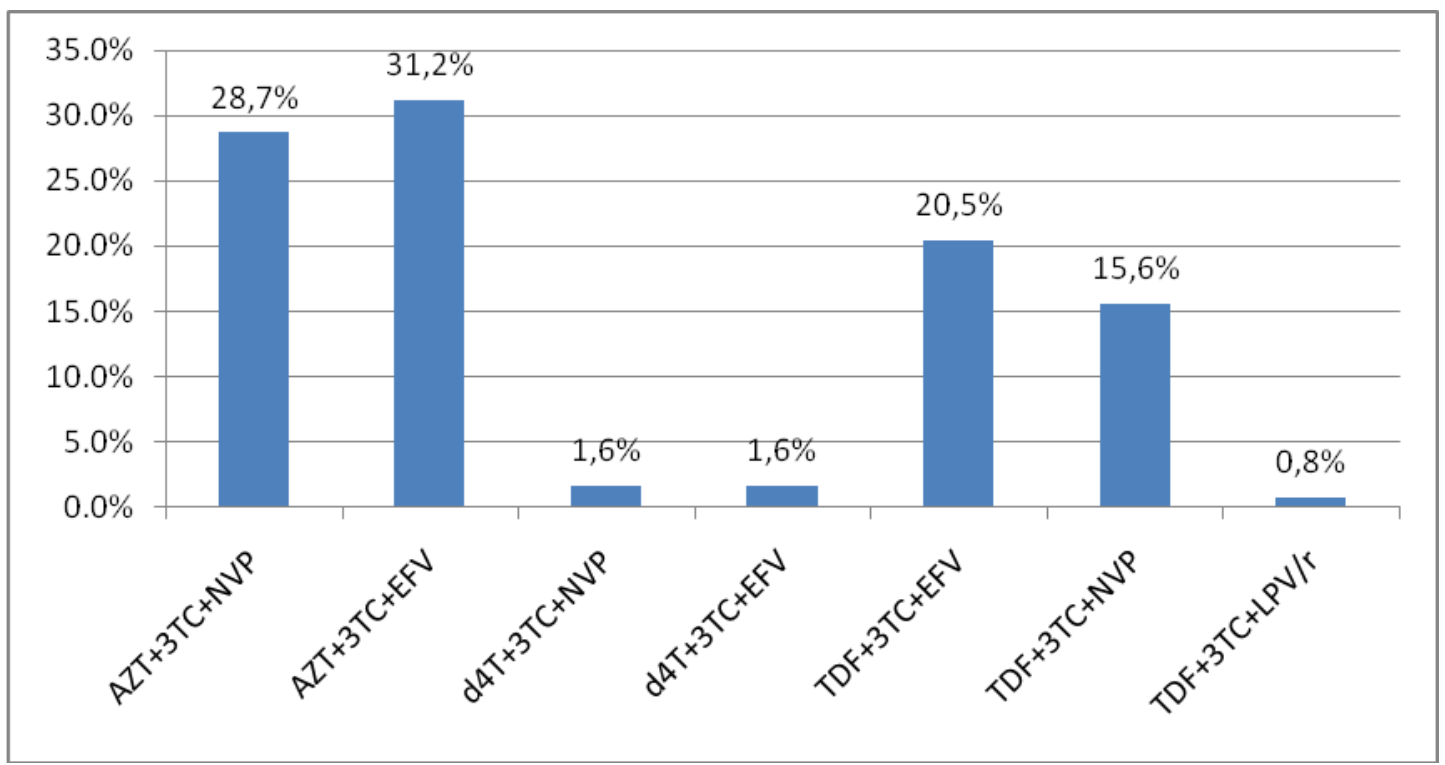

Gambar 1. Persentase pasien berdasarkan penggunaan regimen ARV (Anti Retroviral) pasien HIV/AIDS di Klinik Seroja RSUD Gunung Jati Cirebon Tahun 2013

Pada data yang diperoleh dari persentase pasien berdasarkan penggunaan kombinasi ARV (Anti Retroviral) Pasien HIV/AIDS di Klinik Seroja RSUD Gunung Jati Cirebon Tahun 2013 memperlihatkan kombinasi terbanyak yang digunakan adalah AZT+3TC+EFV sebanyak $31.2 \%$ (38 orang), AZT+3TC+NVP sebanyak 28,7\% (35 orang) dan TDF+3TC+EFV 20,5\% (25 orang). Hasil studi di Brazil pada tahun 2001 - 2003 yang melibatkan 406 orang, terdapat 24,9\% menggunakan kombinasi AZT + 3TC + EFV dan 14,1\% menggunakan kombinasi AZT + 3TC + NVP. Zidovudin merupakan obat pilihan pertama dalam kombinasi rejimen ARV Lini 1. Hal ini karena AZT dapat ditoleransi dengan baik dan juga banyak terdapat sediaan kombinasi (FDC).

Kombinasi yang paling banyak digunakan adalah Zidovudin + Lamivudin + Nevirapine/Efavirenz karena kombinasi ini merupakan kombinasi pilihan pertama yang ditetapkan pemerintah untuk pasien yang tidak mempunyai kelainan fungsi hati dan darah. Lamivudin merupakan pilihan pertama golongan NRTI karena memiliki profil yang aman, efektif untuk hepatitis B, tersedia dan mudah didapat termasuk dalam kombinasi yang tetap. Pilihan obat kedua dari golongan NRTI adalah zidovudin karena efek samping umumnya mudah ditoleransi, jarang menimbulkan komplikasi metabolik. Penggunaan tenofovir pada rejimen ARV ini diberikan sebagai pengganti rejimen ARV sebelumnya. Penggantian ARV pada pasien dapat disebabkan karena alasan toksisitas, dimana pasien tidak mampu menahan adverse drug reaction dari obat sebelumnya, atau dapat disebabkan karena kegagalan terapi sebelumnya, dengan melihat perkembangan penyakit secara imunologis dengan perhitungan $\mathrm{CD}_{4}$ dan / atau secara virologist dengan mengukur viral-load.

\section{Lama terapi ARV}

Pada data subjek penelitian yang diperoleh terlihat gambaran lama terapi ARV (Gambar 2). Diperoleh lama terapi ARV di Klinik Seroja RSUD Gunung Jati Cirebon paling banyak adalah $>2$ tahun -4 tahun sebesar $28,7 \%$ (35 orang), > 1 tahun -2 tahun sebesar 27,0\% (33 orang) dan 3 bulan -1 tahun sebesar $23,8 \%$ (29 orang). Hasil studi adverse drug reaction di Nigeria pada tahun 
2006-2009 yang melibatkan 2456 orang, diperoleh hasil 47,5\% dengan lama terapi ARV antara 12 tahun.

\section{Lama terapi}

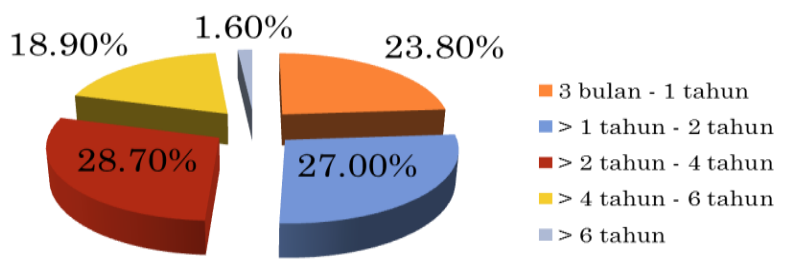

\section{Gambar 2. Diagram lama terapi ARV (Antiretroviral) Pasien HIV/AIDS di RSUD Gunung Jati Cirebon Tahun 2013}

Berdasarkan lama terapi ARV, jenis adverse drug reaction yang terjadi dapat diketahui pada Tabel II berikut ini:

Tabel II. Jenis ADR yang banyak terjadi dilihat dari lama terapi ARV

\begin{tabular}{lcc}
\hline No & Lama terapi ARV & Jenis ADR yang banyak terjadi \\
\hline 1. & 3 bulan -1 tahun & Diare $(\mathrm{n}=18)$ \\
2. & $>1$ tahun -2 tahun & Sakit kepala, anemia, gatal, perubahan warna kulit, neuropati \\
3. & 2 tahun -4 tahun & Kelelahan, mual muntah, lipodistrofi, ruam kulit \\
4. & 4 tahun -6 tahun & Gangguan tidur $(\mathrm{n}=9)$ \\
5. & $>6$ tahun & Gatal $(\mathrm{n}=36)$ \\
\hline
\end{tabular}

Kejadian Adverse Drug Reactions (ADR) Penggunaan Anti Retroviral (ARV)

Adverse drug reactions obat antiretroviral merupakan kejadian yang cukup sering terjadi pada pasien HIV dan umumnya terjadi pada tiga bulan pertama setelah inisiasi ARV, walaupun adverse drug reaction jangka panjang juga kerap didapati sesudahnya.Waktu kejadian adverse drug reaction bervariasi pada setiap individu. Kejadian adverse drug reaction dapat terjadi pada hari pertama sampai beberapa tahun setelah terapi ARV. Variasi kejadian adverse drug reaction inilah yang seringkali menyebabkan kejadian putus obat pada berbagai kasus.

Reaksi obat yang tidak diinginkan (adverse drug reaction) akibat penggunaan terapi Anti retroviral (ARV) pada pasien HIV/AIDS di Klinik Seroja RSUD Gunung Jati Cirebon ada beberapa jenis. Data tersebut diperoleh dari data rekam medik dan daftar pertanyaan peneliti pasien yang diberikan dengan dan tanpa pendampingan dokter di klinik tersebut. Untuk jenis adverse drug reaction yang tidak nampak secara visual maka data diambil berdasarkan pemeriksaan fisik oleh dokter yang ada. Berdasarkan data penelitian yang tertera pada gambar 3, ADR (Adverse Drug Reaction) yang paling banyak terjadi adalah sakit kepala $22,1 \%$ (55 orang), mual/muntah $20,1 \%$ (50 orang), gatal 14,4\% (36 orang).

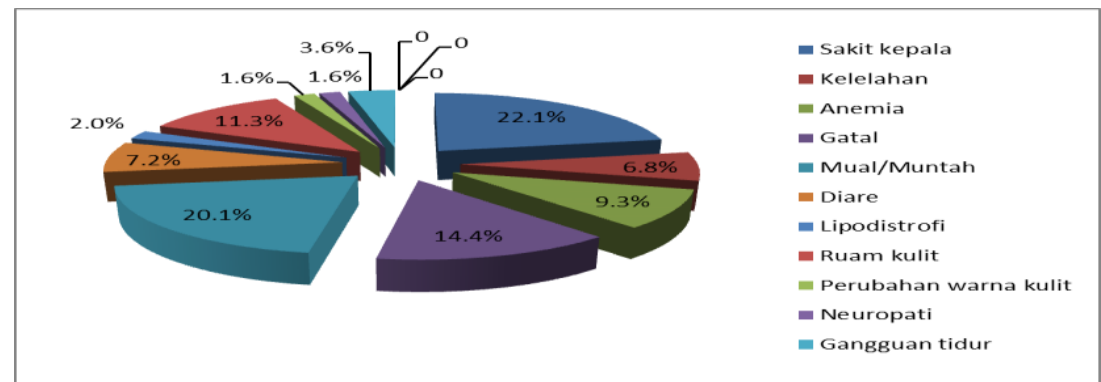

Gambar 3. Persentase ADR (Adverse Drug Reaction) dari penggunaan ARV (Anti Retroviral) Pasien HIV/AIDS di RSUD Gunung Jati Cirebon Tahun 2013 
Berdasarkan jumlah pasien yang menggunakan jenis rejimen ARV yang ditetapkan jenis adverse drug reaction yang terjadi dapat diketahui pada Tabel III berikut ini:

Tabel III. Adverse drug reaction (ADR) Pasien HIV/AIDS di Klinik Seroja RSU Gunung Jati Cirebon Tahun 2013 berdasarkan jumlah pasien yang menggunakan jenis rejimen ARV yang ditetapkan

\begin{tabular}{cccccccc}
\hline Jenis ADR & DN & DE & SHN & SHE & THE & THN & THA \\
\hline Sakit Kepala & 21 & 19 & 0 & 1 & 8 & 6 & 0 \\
Kelelahan & 8 & 5 & 0 & 0 & 2 & 2 & 0 \\
Anemia & 4 & 6 & 0 & 1 & 9 & 3 & 0 \\
Gatal & 8 & 13 & 1 & 0 & 11 & 3 & 0 \\
Mual/muntah & 18 & 13 & 2 & 0 & 8 & 8 & 1 \\
Diare & 3 & 4 & 0 & 0 & 7 & 3 & 0 \\
Lipodistrofi & 0 & 0 & 0 & 0 & 5 & 0 & 0 \\
Hiperkolestrol & 0 & 0 & 0 & 0 & 0 & 0 & 0 \\
Hiperlipidemia & 0 & 0 & 0 & 0 & 0 & 0 & 0 \\
Ruam kulit & 7 & 11 & 1 & 1 & 5 & 4 & 0 \\
Perubahan warna kulit & 1 & 2 & 0 & 0 & 1 & 0 & 0 \\
Neuropati & 0 & 4 & 0 & 0 & 0 & 0 & 0 \\
Gangguan tidur & 4 & 4 & 0 & 0 & 1 & 0 & 0 \\
\hline Total & 74 & 81 & 4 & 3 & 57 & 29 & 1
\end{tabular}

Keterangan:

a. Zidovudin-Lamivudin-Nevirapine /AZT+3TC+NVP (Duviral-Neviral/ DN)

b. Zidovudin-Lamivudin-Efavirenz / AZT+3TC+EFV (Duviral-Efavirenz/ DE)

c. Stavudin-Lamivudin-Nevirapine / d4T+3TC+NVP (Staviral-Hiviral-Neviral/ SHN)

d. Stavudin-Lamivudin-Efavirenz / d4T+3TC+EFV (Staviral-Hiviral-Efevirenz/ SHE)

e. Tenofovir-Lamivudin-Efavirenz/TDF+3TC+EFV(Tenofovir-Hiviral-Efavirenz/THE)

f. Tenofovir-Lamivudin-Nevirapine/TDF+3TC+NVP (Tenofovir-Hiviral-Neviral/THN)

g. Tenofovir-Lamivudin-Lopinavir/Ritonavir/TDF+3TC+LPV/r (Tenofovir-Hiviral-Aluvia/THA).

Berdasarkan Tabel III diatas, Adverse Drug Reaction/ADR yang paling banyak terjadi yaitu sakit kepala dan mual muntah, banyak disebabkan oleh penggunaan rejimen kombinasi Zidovudin-Lamivudin-Nevirapine /AZT +3TC+NVP, sedangkan untuk gatal banyak disebabkan oleh pemakaian rejimen kombinasi Zidovudin-Lamivudin-Efavirenz / AZT+3TC+EFV. Penelitian Ramadian dan Riztriawan yang dilakukan di salah satu rumah sakit umum di Jakarta menemukan adverse drug reaction berupa mual dan gatal banyak disebabkan oleh penggunaan kombinasi Zidovudin-Lamivudin-Nevirapine /AZT+3TC+NVP.

Studi yang dilakukan di Nigeria pada April 2009 - Desember 2010 yang melibatkan 73.589 orang diperoleh ADR sakit kepala, mual muntah, gatal, anemia, diare, ruam kulit, terbanyak disebabkan oleh kombinasi antiretroviral Zidovudin - Lamivudin - Nevirapine (AZT+3TC+NVP). Anemia bisa terjadi karena ADR dari zidovudin atau bisa juga terjadi karena infeksi dari HIV sendiri. Orang dengan HIV lanjut sering mengalami anemia karena tubuhnya tidak lagi (karena berbagai alasan) memproduksi hormon yang dibutuhkan untuk merangsang produksi sel darah merah. Untuk memastikan anemia yang disebabkan ADR dari zidovudin diperlukan pemeriksaan darah lebih lanjut dengan melihat bentuk dan ukuran erirtosit darahnya. Karena zidovudin menghambat sintesis DNA pada proses pembentukan sel-sel darah (eritropoesis), sehingga anemia yang ditimbulkan adalah anemia megaloblastik.

Pada penggunaan antiretroviral terdapat risiko terjadinya anemia 1,5 - 2,3 kali lebih besar tetapi biasanya terjadi pada tahun pertama penggunaan ARV. Obat ARV yang sering disebut sebagai salah satu penyebab anemia adalah inhibitor nucleoside reverse transcriptase yakni zidovudin karena memiliki efek myelotoksisitas lebih tinggi dibanding obat pada kelompok yang sama dan kelompok inhibitor protease. Manifestasi efek samping toksik zidovudin pada sumsum tulang berupa anemia, neutropenia, dan siderosis yang disebabkan oleh inhibisinya pada sintesis 
heme dan globin bersamaan dengan gangguan pada ketersediaan besi. Pengatasan yang dilakukan oleh dokter bila terjadi anemia pada pasien HIV/AIDS adalah memberikan peresepan suplemen atau melakukan transfusi darah bila dirasa perlu. Untuk anemia, bila nilai $\mathrm{Hb}<6,5 \mathrm{~g} \%$ dan/atau jumlah total netrofil $<500 / \mathrm{mm} 3$ maka dilakukan penggantian dengan ARV yang toksisitas sumsum tulangnya rendah (contoh: $\mathrm{d} 4 \mathrm{~T}, \mathrm{ABC}$ atau TDF) dan dipertimbangkan transfusi.

Adverse Drug Reaction (ADR) diare biasanya akan sembuh sendiri tanpa harus menghentikan ARV. Jika diperlukan dapat diberi terapi simtomatis dan rehidrasi dan jaga keseimbangan cairan dan elektrolit. Pada kasus ruam kulit yang ringan, dapat diberikan antihistamin. Ruam sedang yang tidak meluas dan tanpa keterlibatan mukosa dan tanda sistemik, dapat dipertimbangkan untuk mengganti satu NNRTI (NVP diganti EFV). Pada kasus sedang yang memberat, pemberian terapi antiretroviral dihentikan dan diberikan terapi suportif. Setelah sembuh, diganti paduan antiretroviral dengan 3 NRTI atau 2 NRTI + PI .

Keluhan mual muntah sering terjadi karena jalur ARV adalah peroral karena ARV dapat mengiritasi dan meningkatkan asam lambung. Studi yang dilakukan di Brazil pada tahun 2001 2003 melibatkan 406 orang, dimana 13,1\% mengalami adverse drug reaction berupa mual dan 14,5\% mengalami muntah. Sedangkan studi yang dilakukan di Nigeria pada Juli 2010 - Desember 2012 yang melibatkan 215 orang diperoleh 23,4\% mengalami anemia. Penelitian Ramadian dan Riztriawan yang dilakukan di salah satu rumah sakit umum di Jakarta menemukan adverse drug reaction yang terbanyak berupa mual yaitu sebanyak $38 \%$.

Lipodistrofi secara teoritis paling banyak disebabkan oleh kombinasi Stavudin-LamivudinNevirapine /d4T+3TC+NVP. Hasil penelitian Lipodistrofi disebabkan karena penggunaan Tenofovir-Lamivudin-Efavirenz $\quad / T D F+3 T C+E F V \quad$ (Tenofovir-Hiviral-Efavirenz). Perubahan bentuk tubuh pada lipodistrofi dikategorikan menjadi pengurangan lemak perifer (lipoatrofi), penumpukan lemak sentral (lipohipertrofi/lipoakumulasi), dan pola campuran dimana terjadi pengurangan lemak perifer dan penumpukan lemak sentral sekaligus (lipodistrofi). Pada penelitian ini seluruh pasien yang mengalami penumpukan lemak sentral juga mengalami pengurangan lemak perifer, sehingga dapat diketahui bahwa pasien mengalami pola campuran (pengurangan lemak perifer dan penumpukan lemak sentral sekaligus). Pengurangan lemak perifer terjadi pada bagian wajah, lengan, kaki dan bokong. Sedangkan penumpukan lemak sentral terjadi pada bagian tubuh perut dan leher.

Orang terinfeksi HIV mengalami peradangan kronis di seluruh bagian tubuh, akibatnya tubuh memberikan reaksi juga terhadap metabolisme lemak dan glukosa, sehingga sering dikaitkan dengan sindroma metabolik. Komplikasi metabolik yang terjadi karena infeksi HIV dan penggunaan antiretroviral terutama PI adalah karena resistensi insulin yang menyebabkan penurunan kapasitas jaringan adipose perifer untuk menyimpan lemak, dan lemak yang beredar disimpan di daerah viseral.

Hal ini menyebabkan rasio lemak viseral (perut) dan pinggul meningkat sedangkan di tempat lain terjadi atrofi lemak subkutan terutama daerah muka dan paha. Perubahan kadar kolesterol, trigliserida dan glukosa plasma juga sering terlihat. Stres oksidatif yang diinduksi oleh NRTI dan PI pada sel lemak mungkin salah satu faktor utama terbentuknya lipodistrofi. PI menurunkan ekspresi PPAR gamma, mekanisme genetik untuk program diferensial dan sensitifitas insulin, yang pada akhirnya menyebabkan lipoatrofi. Stavudin dan lamivudine, golongan NRTI analog timidin, memiliki faktor resiko yang besar untuk menimbulkan lipodistrofi, sebab itu beberapa penelitian membuktikan sekaligus menganjurkan agar penggunaan analog timidin diganti dengan analog non-timidin, misalnya Abacavir atau tenofovir. ADR hiperkolesterol dan hiperlipidemia pada penelitian ini tidak dapat diketahui karena keterbatasan tidak dilakukannya pemeriksaan laboratorium pada pasien.

Data penelitian terlihat ADR neuropati terjadi karena penggunaan kombinasi ZidovudinLamivudin-Efavirenz / AZT+3TC+EFV. Keluhan yang dirasakan pasien adalah kesemutan pada telapak tangan dan kaki dengan frekuensi nyeri hanya sesekali muncul. Studi yang dilakukan di Nairobi pada tahun 2005-2008 yang melibatkan 2092 orang dimana 85\% (1781 orang) menggunakan $\mathrm{d} 4 \mathrm{~T}+3 \mathrm{TC}+\mathrm{NVP} / \mathrm{EFV}$ dan $15 \%$ (311 orang) menggunakan $\mathrm{AZT}+3 \mathrm{TC}+\mathrm{NVP} / \mathrm{EFV}$ 
insiden neuropati adalah 20,4\% untuk stavudin dan 3,4\% untuk zidovudin. Sehingga dapat disimpulkan bahwa resiko terjadinya neuropati adalah lebih besar stavudin daripada zidovudin.

\section{KESIMPULAN}

Regimen ARV yang paling banyak digunakan adalah kombinasi Zidovudin + Lamivudin + Nevirapine/Efavirenz (AZT+3TC+EFV) sebanyak 31.2\% (38 orang). Lama terapi ARV di Klinik Seroja RSUD Gunung Jati Cirebon paling banyak adalah > 2 tahun -4 tahun sebesar 28,7\% (35 orang). Jenis adverse drug reaction (ADR) yang terjadi pada penggunaan obat antiretroviral pada pengobatan pasien HIV/AIDS di RSUD Gunung Jati Cirebon adalah: sakit kepala $(22,1 \%)$, kelelahan $(6,8 \%)$, anemia $(9,3 \%)$, gatal $(14,4 \%)$, mual/muntah $(20,1 \%)$, diare $(7,2 \%)$, lipodistrofi $(2,0 \%)$, ruam kulit $(11,3 \%)$, perubahan warna kulit $(1,6 \%)$, neuropati $(1,6 \%)$ dan gangguan tidur $(3,6 \%)$.

\section{DAFTAR PUSTAKA}

Anonim. 2013. Statistik Kasus HIV/AIDS di Indonesia Dilapor s/d September. Kementerian Kesehatan Republik Indonesia. Jakarta. http://spiritia.or.id/Stats/StatCurr.pdf. 10 Februari 2014.

Anonim. 2004. National Antiretroviral Treatment Guideline. National Department of Health. South Africa. http://www.hst.org.za/uploads/files/sa_ART_Guidelines1.pdf. 10 Februari 2014.

Anonim. 2004. Keputusan Menteri Kesehatan Republik Indonesia Tentang Standar Pelayanan Farmasi di Rumah Sakit. Departemen Kesehatan RI. Jakarta. http://sinforeg.litbang.depkes.go.id/upload/regulasi/PMK_No._58_ttg_Standar_Yanfar_RS_.p df. 11 Februari 2014.

Anonim. 2012. Laporan situasi perkembangan HIV/AIDS di Indonesia sd 30 Juni 2012. Ditjen PP\&PL Kementrian Kesehatan RI. Jakarta. http://pppl.depkes.go.id/_asset/_download/Laporan\%20HIV\%20AIDS\%20TW\%204\%202012 .pdf. 11

Anonim. 2013. Laporan situasi perkembangan HIV/AIDS di Indonesia sd 30 Juni 2013. Ditjen PP\&PL Kementrian Kesehatan RI. Jakarta. http://pppl.depkes.go.id/_asset/_download/Laporan\%20HIV\%20AIDS\%20TW\%204\%202013 .pdf. 11 Februari 2014.

Dyke, V.K., Karen, W., 2006, Modern Pharmacology With Clinical Applications, Therapy of Human Immunodeficiency Virus: 584.

Henry, L., Simon, P., 2012, Adverse drug reactions of highly active antiretroviral therapy (HAART) in HIV infected patients at The general hospital Douala, Cameroon: a cross sectional study, pan African Medical Journal: 1-7.

Kenneth, A.A., Isah, M.A., Doroty, A., 2013, Incidence of Adverse Drug reactions in patiens on Antiretroviral theraphy, A study of pharmaceutical care in HIV interventions in Nigeria, West Africans Journal of Pharmacy, 30-42.

McLigeyo, A., Lule, G., Otieno, F.C.F., Kayima, J.K., Omonge, E., 2012, Metabolic factors associated with the development of lipodystrophy in patients on long-term highly active anti-retroviral therapy (HAART), Kenya: 142-148

McLigeyo, A.A., Lule, G., Otieno, F.C.F., Kayima, J.K.,Omonge, E., 2012, Human immunodeficiency virus (HIV) associated lipodystrophy: The prevalence, severity and phenotypes in patients on highly active anti-retroviral therapy (HAART) in Kenya, Kenya: 103-113.

Menezes, C,A., Cesar, P.F., Bonolof, A., Acurcio, M.D.C., 2006, High incidence of adverse drug reactions to initial antiretroviral therapy in Brazil, Brazilian Journal of medical and biological research: 39, 495-505.

Montessori, V., Press, N., Harris, M., Akagi, L., Montainer, J., 2004, Adverse Effect of Antiretroviral Theraphy for HIV Infection, Canadian Medical Association or its Licensors: 229-238.

Qamariyah, S.K., 2012, Normalina, I., Nasronudin, Indonesian Jurnal of tropical and infectious disease, Surabaya: 96-99.

Ramadian, O. Riztriawan E. 2010. Pengaruh Efek Samping ARV Lini Pertama terhadap adherens pada ODHA di Layanan Terpadu HIV, RSCM: Jakarta: 19-20. 
Silva Alchieri. 2013. Lipodystrophy, "social death" and treatment adherence in human immunodeficiency virus/acquired immune deficiency syndrome (HIV/AIDS): Brazil: 149-156.

Thorp C. 2008. Pharmacology for the Health Care Professions. $1^{\text {st }}$ edition.UK: Wiley Blackwell. : 162 